\title{
Identification, Mapping, Cloning and Characterization of a Gene (sbmA) Required for Microcin B17 Action on Escherichia coli K12
}

\author{
By MAGELA LAVIÑA', ANTHONY P. PUGSLEY ${ }^{2}$ \\ AND FELIPE MORENO ${ }^{1 *}$ \\ 'Unidad de Genética Molecular, Servicio de Microbiología, Hospital Ramón y Cajal, \\ Carretera de Colmenar, Km 9.1, Madrid 28034, Spain \\ 'Unité de Génétique Moléculaire, Institut Pasteur, 25 rue du Dr Roux, \\ Paris 75724 Cedex 15, France
}

(Received 30 September 1985; revised 4 December 1985)

\begin{abstract}
We have identified mutations in three different chromosomal genes of Escherichia coli $\mathrm{K} 12$ which reduce sensitivity to microcin B17. Mutations in $o m p F$ and $o m p R$ genes affected production of an outer membrane porin protein, $\mathrm{OmpF}$, and resulted in reduced sensitivity to a number of other agents (colicins, bacteriophages) besides microcin B17. The third class of mutants were specifically and highly resistant to microcin $\mathrm{B} 17$. The mutations in these strains were mapped to a gene $(\operatorname{sbm} A)$, located at $8.7 \mathrm{~min}$ on the $E$. coli $\mathrm{K} 12$ chromosome, which is closely linked to phoA. The wild-type $\operatorname{sbm} A$ allele was cloned into multiple copy number plasmids, and its location within the cloned DNA fragment was further defined by mutagenesis with MiniMudII1681. These insertion mutations resulted in in-frame fusions between the $s b m A$ and $l a c Z$ genes, thereby allowing us to determine the direction of $\operatorname{sbm} A$ gene transcription. Plasmids carrying these gene fusions produced low levels of $\beta$-galactosidase, indicating that the $s b m A$ gene is poorly expressed. We have been unable to identify the $\operatorname{sbmA}$ gene product, but indirect evidence indicates that it might be an envelope protein involved in microcin uptake.
\end{abstract}

\section{INTRODUCTION}

Microcin B17 is a polypeptide antibiotic of approximately $4000 M_{\mathrm{r}}$ produced by Escherichia coli strains harbouring plasmid pMccB17 (pRYC17) (Asensio et al., 1976; Baquero et al., 1978; Herrero \& Moreno, 1986). The genetic determinants involved in microcin B17 production reside in a $3.8 \mathrm{~kb}$ stretch of plasmid DNA that contains four cistrons, all of which are required for antibiotic production (San Millán et al., 1985a,b). Microcin B17 production also requires the expression of three chromosomal loci, one of which is the $o m p R$ gene (Hernández-Chico et al., 1982; Baquero \& Moreno, 1984). Unlike the production of most colicins, that of microcin B17 is not lethal and is not induced by DNA-damaging agents (Baquero \& Moreno, 1984; Pugsley, 1984).

The activity spectrum of microcin $\mathrm{B} 17$ is restricted to a few species of bacteria related to $E$. coli. The antibiotic specifically inhibits DNA synthesis in susceptible E. coli $\mathrm{K} 12$ strains; DNA is degraded, and the cells die. Consequently, the so-called SOS system is derepressed in microcin B17-treated cells. This expression requires the products of the $\operatorname{rec} A$ and $\operatorname{rec} B C$ genes and an active replication fork. Mutations in $\operatorname{rec} A$ or $\operatorname{rec} B C$ enhance microcin $\mathrm{B} 17$ sensitivity, whereas lexA (Def) mutations reduce it (Herrero \& Moreno, 1986).

As another approach to the study of microcin B17 action, we have isolated and characterized microcin $\mathrm{B} 17$ insensitive mutants of $E$. coli $\mathrm{K} 12$. In this article, we identify three chromosomal genes whose products are required for microcin action, and report the cloning and characterization of one of them which seems to be specifically involved in microcin action.

Abbreviations: B17 $7^{\mathrm{R}}$, microcin B17 resistance; XP, 5-bromo-4-chloro-3-indolylphosphate; X-gal, 5-bromo-4chloro-3-indolyl $\beta$-D-galactoside; AU, arbitrary antibiotic unit: IPTG, isopropyl- $\beta$-D-galactopyranoside. 


\section{METHODS}

Bacterial strains, plasmids and bacteriophages. Those used are listed in Table 1.

Media and chemicals. LB medium and M63 minimal medium (Miller, 1972) were used throughout. M63 medium was supplemented with thiamin $\left(1 \mu \mathrm{g} \mathrm{ml}^{-1}\right)$, glucose $(0.2 \%)$ or lactose $(0.2 \%)$, and, where necessary, with L-amino acids $\left(20 \mu \mathrm{g} \mathrm{ml}^{-1}\right)$. Antibiotics were used at the following concentrations: ampicillin (Ap), $50 \mu \mathrm{g} \mathrm{ml}^{-1}$; tetracycline (Tc), $20 \mu \mathrm{g} \mathrm{ml}^{-1}$; streptomycin $(\mathrm{Sm}), 100 \mu \mathrm{g} \mathrm{ml}^{-1}$; sodium nalidixate ( $\left.\mathrm{Nal}\right), 40 \mu \mathrm{g} \mathrm{ml}^{-1}$; kanamycin $(\mathrm{Km}), 30 \mu \mathrm{g} \mathrm{ml}^{-1}$. Phage $\mathrm{Pl}$ was grown on LB agar supplemented with $2.5 \mathrm{mM}-\mathrm{CaCl}_{2}, 0.2 \%$ glucose and $1.2 \%$ Difco agar. Alkaline phosphatase-producing $\left(\mathrm{PhoA}^{+}\right)$strains were scored on MOPS/glucose medium supplemented with $10^{-4} \mathrm{M}$-potassium phosphate (Neidhardt et al., 1974) and containing $40 \mu \mathrm{g} \mathrm{XP} \mathrm{(5-bromo-4-}$ chloro-3-indolylphosphate) $\mathrm{ml}^{-1}$ as chromogenic alkaline phosphatase substrate. Production of $\beta$-galactosidase $\left(\mathrm{LacZ}^{+}\right)$was detected on LB agar plates containing $20 \mu \mathrm{g} \mathrm{X}$-gal (5-bromo- ${ }^{-}$-chloro-3-indolyl $\beta$-D-galactoside) $\mathrm{ml}^{-1}$ (Miller, 1972). Microcin insensitive mutants were selected on M63 glucose or LB agar plates containing crude microcin (50 AU ml-1). Microcin was prepared using the overproducing strain RYC893 and assayed as described below.

Microcin, colicin and phage sensitivity. Microcin B17 sensitivity was determined by allowing drops of a suspension of strain RYC893 to run in a straight line on M63 glucose plates. After $30 \mathrm{~h}$ incubation, strains to be tested were cross-streaked and the plates reincubated. Only resistant clones grew in the vicinity of the microcinogenic bacteria. The critical dilution method (Mayr-Harting et al., 1972) was used for more accurate determinations of microcin sensitivity. Colicin sensitivity was also determined by the cross streak method using the strains listed by Pugsley (1985). Phage sensitivity was determined by cross-streaking using phages TuIa $\left(5 \times 10^{7}\right.$ p.f.u. $\left.\mathrm{ml}^{-1}\right)$ and $\lambda \mathrm{Vh} 434\left(1 \times 10^{8}\right.$ p.f.u. $\left.\mathrm{ml}^{-1}\right)$.

Transposon Tn 5 mutagenesis. Five cultures of strain BM21 were incubated at $30^{\circ} \mathrm{C}$ with phage $\lambda .467$ (rex::Tn5) according to Berg (1977). After $20 \mathrm{~min}$, the mixture was diluted into 9 vols L broth and incubated for $2 \mathrm{~h}$ at $42^{\circ} \mathrm{C}$ to allow expression of kanamycin resistance. Samples from each culture were then plated on M63 glucose medium containing $\mathrm{Km}$ and microcin $\mathrm{B} 17$, and incubated at $42{ }^{\circ} \mathrm{C}$.

Genetic techniques. Conjugation and P1 transduction were done as described by Miller (1972). Plasmid DNA was extracted from overnight LB cultures. Cleared lysates were obtained and DNA was precipitated as described by Maniatis et al. (1982). Digestion with restriction endonucleases, ligation with T4 DNA ligase and transformation were all done as described by Davis et al. (1980). Agarose gel electrophoresis was done in a vertical slab apparatus using Tris/phosphate buffer (Davis et al., 1980). The sizes of restriction endonuclease fragments were determined by comparing their mobilities with $H$ indIII fragments of phage $\lambda$ DNA (Sanger et al., 1982) or with HaeIII fragments of phage $\phi$ X174 replicative DNA (Sanger et al., 1978) in 0.6-1.2\% agarose gels.

Construction of pMM100. The expression vector pUC13 (Messing, 1983) was used to clone $s b m A^{+}$under lacZp control. In order to avoid problems caused by the poor growth of cells carrying this pUC13 derivative, we first constructed a compatible, multiple copy number plasmid carrying the $l a c I^{q 1}$ allele of the lactose repressor gene (Calos \& Miller, 1981). An EcoRI fragment of $\mathrm{pLi} 7$ (Table 1) containing lac I $^{\mathrm{1} 1}$ was extracted from an agarose gel and ligated into the EcoRI site of pACYC184. The resulting plasmid, pMM100, was shown to repress lac $Z^{+}$ expression in cells devoid of the chromosomal lacI gene. lacZ expression remained inducible by IPTG.

sbmA : :MudII1681 gene fusions in pMM73-4. Strain POII1681(pMM73-4) was used to produce transducing particles. These were used to infect strain RYC761 as described by Castilho et al. (1984). The transduction mixture was incubated for $3 \mathrm{~h}$ at $30^{\circ} \mathrm{C}$ to allow expression of kanamycin resistance, and was then plated onto LB Km Tc $\mathrm{X}$-gal agar containing microcin B17. Nine experiments were done in order to obtain independent insertions. $\beta$-Galactosidase was assayed according to Miller (1972).

\section{RESULTS}

Isolation of microcin B17-resistant mutants. Spontaneous resistant mutants were obtained at frequencies of about $1 \times 10^{-6}$ when sensitive $E$. coli $\mathrm{K} 12 \mathrm{BM} 21$ or RYC10 cells were plated on selective agar containing microcin B17. The mutants appeared at about 10 times this frequency when Tn5-mutagenized bacteria were used.

Mutations in ompR and ompF cause microcin resistance. Mutants obtained by the above procedure were tested for their sensitivity to various bacteriophages and colicins. A small proportion were resistant to bacteriophage TuIa or TuIa plus $\lambda \mathrm{Vh} 434$, and exhibited substantially reduced sensitivity to colicins A, E2 through E8, K, L, S4 and N. An examination of their outer membrane protein profiles by SDS-PAGE revealed that they were devoid of major outer membrane proteins OmpF $\left(\mathrm{TuIa}^{\mathrm{R}}, \lambda \mathrm{Vh} 434^{\mathrm{S}}\right)$ or OmpF plus OmpC $\left(\mathrm{TuIa}^{\mathrm{R}}, \lambda \mathrm{Vh} 434^{\mathrm{R}}\right)$, which agrees with the fact that these phages use $\mathrm{OmpF}$ or OmpC respectively as their receptors 
Table 1. Bacterial strains, bacteriophages and plasmids

E. coli strain

pop 3000

GM247

RYC22

RYC893

BM21

RYC10

RYC816

MC4100

SM 125

MH150

RYC514

$\mathrm{MH} 407$

SM547

RYC717

RYC714

RYC726

RYC730

RYC760

RYC745

RYC761

RYC953

POII1681

Bacteriophage

$\lambda 467$

MuctsApR

Plasmid

pMM 102

pL719

$\mathrm{pLi} 7$

pUC13

pAPIP502
Genotype/phenotype

$\mathrm{HfrH}$

$\mathrm{HfrH}$ ProC- $\mathrm{PyrD}^{-} \mathrm{Sp}^{\mathrm{k}+}$

$\mathrm{F}^{-}$his-4 $\mathrm{Thr}^{-} \mathrm{Leu}^{-} \mathrm{ProA}^{-} \mathrm{ArgE}^{-} \mathrm{Gal}^{-} \mathrm{Xyl}^{-}$

LacY- $\mathrm{Tsx}^{k} \mathrm{ThiA}^{-} \mathrm{Str}^{k} \mathrm{Nal}^{\mathrm{R}}$

$F^{-}$araDl39 NacU169 AmalBI Str ${ }^{R}$ RelA $^{-}$

ThiA- (pMM102)

$\mathrm{F}^{-} \mathrm{Nal}^{\mathrm{R}}\left(\lambda^{+}\right)$

BM21 RpoB-

BM21 rec A56 srl : $: \operatorname{Tn} 10_{+}^{+}$

$\mathrm{F}^{-}$araDI39 NlacU169 $\mathrm{Str}^{\mathrm{R}} \mathrm{ThiA}^{-}$RelA-

MC4100 PhoA ${ }^{-}$proC:: $\operatorname{Tn} 5$

MC4 100 ompC::Tn5

MC4100 ompR101

MC4 100 malQ7 ompF7:: Mucts

$\mathrm{F}^{-} \mathrm{Leu}^{-} \mathrm{PhoR}^{-} \Lambda(\operatorname{sbm} A$ phoA proC $)$

ts. : : Tn 5

BM2I $\operatorname{sbm} A I$

BM21 sbmA11:: Tn5

RYC10 (phoA sbmA $) 14$

MC4100 sbmAl PhoA-

RYC730 rec A56 srl : : Tn 10

RYC22 sbmA1l:: Tn5

MC4100 $\Delta(p h o A s b m A) 14$ MuctsAp ${ }^{R}$

BM21 $\Lambda(s b m A$ phoA proC) ts.x::Tn5

AraD- $\Lambda$ (ara leu) $7697 \Lambda($ proAB arg $F$ lac)X1// Str $^{\mathrm{R}}$ Mucts MudIII681

$\lambda c 1857$ rex::Tn5\$ Oam29 Pam80 b221

Mucts carrying bla derived from $\mathrm{Tn} 3$

pBR322:: $\mathrm{MccB} 17^{+} \mathrm{MccB} 17^{\mathrm{imm}}$

ColEl $s b m A^{+}$pho $A^{+}$proC $C^{+}$pho $B^{+}$

pBR322 lac ${ }^{41}$ lac $Z^{\prime}$

bla lac Z'

$\mathrm{F}^{\prime}$ lacZM15 lac ${ }^{91} \mathrm{Tn} 10$
Source and/or reference*

M. Schwartz

R. D'Ari

Laboratory collection

San Millán et al. (1985a)

Hernández-Chico et al. (1982)

Laboratory collection

Hernández-Chico et al. (1982)

Casadaban (1976)

S. Michaelis

Hall \& Silhavy (1979)

Laboratory collection

Hall \& Silhavy (1981)

S. Michaelis

This work; spontaneous mutant

Tn5-generated $B 17^{R}$ mutant

Spontaneous $B 17^{R}$ mutant

$\mathrm{Pro}^{+} \mathrm{PhoA}^{-} \mathrm{B} 17^{\mathrm{R}}$ transductant of SM125

via $\mathrm{Pl}$ grown on $\mathrm{RYC} 717$

$\mathrm{Tc}^{\mathrm{R}} \mathrm{Rec}^{-}$transductant of RYC730

via $\mathrm{P} 1$ grown on RYC816

$\mathrm{Km}^{\mathrm{R}} \mathrm{B} 17^{\mathrm{R}}$ transductant of $\mathrm{RYC} 22$ via $\mathrm{P} 1$ grown on RYC714

Mu lysogen of $\mathrm{Pro}^{+} \mathrm{PhoA}^{-} \mathrm{B} 17^{\mathrm{R}}$

transductant of SM125 via $\mathrm{P} 1$ grown

on RYC726

$\mathrm{Km}^{\mathrm{R}} \mathrm{Pro}^{-} \mathrm{B} 17^{\mathrm{R}}$ transductant of $\mathrm{BM} 21$ via

P1 grown on SM547

Castilho et al. (1984)

Berg (1977)

W. Schuman

San Millán et al. (1985b)

Clarke and Carbon collection via R. Portalier

B. Müller-Hill

Messing (1983)

Laboratory collection

* Addresses: M. Schwartz, Institut Pasteur, Paris, France; R. D’Ari, Institut Jacques Monod, Paris, France; S. Michaelis, Harvard Medical School, Boston, USA; W. Schuman, Tecnische Hochschule, Darmstadt, FRG; R. Portalier, Université Claude Bernard, Lyon, France; B. Müller-Hill, Universität Köln, Cologne, FRG.

$\dagger \mathrm{Sp}^{\mathrm{R}}$, spectinomycin resiștant.

\$ The recA56 allele was introduced into several strains by contransduction with $s r l:: \mathrm{Tn} I 0$ using $\mathrm{Pl}$ grown on strain RYC816. $\mathrm{Tc}^{\mathrm{R}}$ transductants were selected, and $\mathrm{RecA}-$ clones were detected by their increased sensitivity to UV light.

$\S$ Tn5 confers kanamycin resistance.

(Datta et al., 1977; Hankte, 1978). Mutations which reduce production of OmpF or OmpF plus OmpC proteins are also known to cause reduced sensitivity to several colicins (Pugsley, 1984).

Mutations in two different genes are known to produce the phenotype(s) we have described above for the microcin resistant mutants: mutations in $o m p F$, the structural gene for the OmpF protein, cause specific loss of $\mathrm{OmpF}$, whereas mutations in $\operatorname{omp} R$, a positive regulator gene, often result in failure to produce OmpF and OmpC proteins (Hall \& Silhavy, 1981). The genetic location of two of each class of mutations selected by their microcin $\mathrm{B} 17$ resistance phenotype was confirmed as $o m p F$ or ompR by $\mathrm{P} 1$ transduction experiments. The $\mathrm{TuIa}^{\mathrm{R}} \mathrm{B} 17^{\mathrm{R}}$ (microcin B17 resistance) mutation was $50 \%$ cotransduced with pyrD $(21 \mathrm{~min})$, and the $\mathrm{TuIa}^{\mathrm{R}} \mathrm{B} 17^{\mathrm{R}}$ 
Table 2. Transduction mapping of sbmA11::Tn5 mutation

Phage PI grown on strain RYC745 ( $\mathrm{Lac}^{-} s b m A 11::$ Tn5 ProC $\left.{ }^{+} \mathrm{Tsx}^{-}\right)$was used to infect strain GM247 $\left(\mathrm{Lac}^{+} \mathrm{SbmA} A^{+}\right.$ProC $\left.{ }^{-} \mathrm{Tsx}^{+}\right) . \mathrm{Km}^{R}$ and $\mathrm{Pro}^{+}$transductants were selected and scored for unselected markers. The $\mathrm{Sbm}^{+}$phenotype was checked by cross-streaking, and the $\mathrm{Tsx}^{+}$phenotype by sensitivity to bacteriophage $\mathrm{T} 6\left(\mathrm{Tsx}^{-}\right.$mutants are $\left.\mathrm{T} 6^{\mathrm{R}}\right)$.

\begin{tabular}{|c|c|c|c|c|c|c|c|}
\hline \multicolumn{4}{|c|}{$\begin{array}{c}\mathrm{Km}^{\mathrm{R}}(\operatorname{shm} A 11:: \mathrm{Tn} 5) \text { transductants } \\
\text { (97 analysed) }\end{array}$} & \multicolumn{4}{|c|}{$\begin{array}{l}\text { Pro }^{+} \text {transductants } \\
\quad(148 \text { analysed })\end{array}$} \\
\hline \multicolumn{3}{|c|}{$\begin{array}{l}\text { Non-selected } \\
\text { markers }\end{array}$} & \multirow{2}{*}{$\begin{array}{c}\text { No. of } \\
\text { transductants }\end{array}$} & \multicolumn{3}{|c|}{$\begin{array}{l}\text { Non-selected } \\
\text { markers }\end{array}$} & \multirow{2}{*}{$\begin{array}{l}\text { No. of } \\
\text { transductants }\end{array}$} \\
\hline Lac & ProC & $\overbrace{\operatorname{Tsx}}$ & & $\mathrm{Lac}$ & SbmA & $\overbrace{\mathrm{Tsx}}$ & \\
\hline- & - & - & 0 & - & - & - & 0 \\
\hline - & - & + & 3 & - & - & + & 4 \\
\hline- & + & - & () & - & + & - & 0 \\
\hline- & + & + & 1 & - & + & + & 0 \\
\hline+ & - & - & 2 & + & - & - & 28 \\
\hline+ & - & + & 28 & + & - & + & 101 \\
\hline+ & + & - & 15 & + & + & - & 3 \\
\hline+ & + & + & 48 & + & + & + & 12 \\
\hline
\end{tabular}

Table 3. Transduction mapping of the spontaneous sbmAl mutation

Strain SM125 (SbmA+ PhoA $^{-} \mathrm{ProC}^{-}$) was transduced with phage $\mathrm{P} 1$ grown on strain $\mathrm{RYC} 717$ ( $s b m A 1$ $\mathrm{PhoA}^{+} \mathrm{ProC}^{+}$) with selection for $\mathrm{Pro}^{+}$transductants; 199 of these transductants were tested.

\begin{tabular}{|c|c|c|}
\hline \multicolumn{2}{|c|}{ Unselected markers } & \multirow{2}{*}{$\begin{array}{c}\text { No. of } \\
\text { transductants }\end{array}$} \\
\hline SbmA & PhoA & \\
\hline+ & + & 18 \\
\hline+ & - & 10 \\
\hline- & + & 170 \\
\hline- & - & 1 \\
\hline
\end{tabular}

$\lambda \mathrm{Vh} 434^{\mathrm{R}}$ mutation was $80 \%$ cotransduced with $\mathrm{mal} A(75 \mathrm{~min})$. These are the expected linkages for $o m p F$ and $o m p R$ loci respectively (Bachmann, 1983). In addition, well-characterized mutations in $o m p R$ and in $o m p F$ were also found to confer microcin B17 resistance (see Table 4).

Mutants specifically resistant to microcin B17. Approximately $80 \%$ of the mutants we obtained were specifically resistant to microcin B17, and remained sensitive to all other agents tested. We first studied mutants of this type obtained after transposon Tn 5 mutagenesis. Absolute linkage of Tn5-encoded kanamycin resistance and microcin B17 resistance was first tested by $\mathrm{P} 1$ phage transduction, thereby confirming that $\mathrm{Tn} 5$ was inserted in the gene required for microcin sensitivity. One such strain used for further analysis was RYC714, and the locus affected was termed $\operatorname{sbm} A$ (sensitivity to $B 17 \mathrm{microcin}$ ). The $s b m A 11:: \operatorname{Tn} 5$ mutation was transduced into strain pop3000 $(\mathrm{HfrH})$, which was then conjugated with strain $\mathrm{RYC} 22\left(\mathrm{Thr}^{-} \mathrm{Leu}^{-} \mathrm{ProA}^{-}\right.$ $\mathrm{LacY}^{-} \mathrm{Tsx}^{-} \mathrm{Nal}^{\mathrm{R}}$ ) with selection for $\mathrm{Km}^{\mathrm{R}}$ and counter selection for $\mathrm{Nal}^{\mathrm{R}}\left(\mathrm{GyrA}^{-}\right)$. This experiment demonstrated a close linkage between $\operatorname{sbmA11}:$ :Tn 5 and $l a c Y$. The results of $\mathbf{P} 1$ transduction experiments reported in Table 2 confirmed this linkage, and showed that the sbmA11:: Tn 5 mutation was $90 \%$ cotransduced with the proC gene being located between this marker and lac. Other transduction experiments showed that the spontaneous $s b m A I$ mutation was also cotransduced with proC $(86 \%)$ and was located to the left of phoA (Table 3). All these data indicate that $s b m A$ maps at approximately $8.7 \mathrm{~min}$ on the $E$. coli linkage map with the following order of markers: lac-sbmA-phoA-proC.

Several other independent $\mathrm{Tn} 5$ and spontaneous microcin B17-resistant mutants were also analysed by $\mathrm{P} 1$ transduction to localize their mutations. They all showed high cotransduction $(85-90 \%)$ with proC. In addition, a significant proportion of mutants were also unable to 
Table 4. Microcin BI7 sensitivity of E. coli KI2 strains carrying recA, sbmA and mutations affecting porin production

Microcin sensitivity was measured by the critical dilution assay on LB agar plates. The strains used

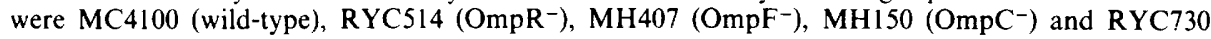
$\left(\mathrm{SbmA}^{-}\right)$, and their rec $A 56 \mathrm{srl}:: \mathrm{Tn} / 0$ derivatives. The experiments were done at $30^{\circ} \mathrm{C}$.

\begin{tabular}{|c|c|c|c|c|c|}
\hline \multicolumn{5}{|c|}{ Phenotype } & \multirow[b]{2}{*}{ Microcin titr } \\
\hline $\operatorname{RecA}$ & OmpR & OmpF & OmpC & SbmA & \\
\hline+ & + & + & + & + & 8 \\
\hline- & + & + & + & + & 128 \\
\hline+ & - & + & + & + & $<1$ \\
\hline- & - & + & + & + & I \\
\hline+ & + & - & + & + & 1 \\
\hline- & + & - & + & + & 16 \\
\hline+ & + & + & - & + & 4 \\
\hline- & + & + & - & + & 32 \\
\hline+ & t & + & + & - & $<1$ \\
\hline- & + & + & + & - & $<1$ \\
\hline
\end{tabular}

produce alkaline phosphatase on XP plates, indicating that they probably carried deletion mutations affecting $s b m A$ and $p h o A$. We conclude that all these mutants are affected in the same locus, $s b m A$.

Two $\mathrm{F}^{\prime}$ factors ( $\mathrm{F}^{\prime} \mathrm{W} 3747$ and $\mathrm{X} 573$; Low, 1972) carrying the 8-9 min region of the $E$. coli $\mathrm{K} 12$ chromosome were introduced into strain RYC760 (SbmA $\left.{ }^{-} \mathrm{PhoA}^{-} \mathrm{Lac}^{-} \mathrm{RecA}^{-}\right)$. They complemented the $\operatorname{sbmA}$ mutation, and the normal level of microcin B17 sensitivity was recovered. The $s b m A$ mutation is, therefore, recessive to the wild-type allele.

Levels of microcin B17 resistance. Strains carrying $\operatorname{rec} A$ mutations are about 10 times more sensitive to microcin B17 than strains with the rec $A^{+}$allele (Herrero \& Moreno, 1986). The critical dilution method was used to evaluate the level of microcin $\mathrm{B} 17$ resistance afforded by $o m p F, o m p C$, ompR and $s b m A$ mutations in strains also carrying $r e c A^{+}$or $r e c A$ alleles. Strains carrying ompR or omp $F$ mutations were only partially resistant to microcin $\mathrm{B} 17$, whereas strains carrying the $s b m A$ mutation were completely resistant. ompC mutations resulted in a slightly decreased sensitivity (Table 4).

Cloning of sbmA into pBR322. Plasmid pL719, from the Clarke and Carbon collection (Clarke \& Carbon, 1976), carries the $p h o A^{+}$, pro $C^{+}$and $p h o B^{+}$alleles (R. Portalier, personal communication), and was found to complement $\operatorname{sbm} A$ mutations. It was transferred by $\mathrm{F}$ duction to strain RYC953 ( $\mathrm{SbmA}^{-} \mathrm{ProC}^{-}$), with selection on minimal medium without proline. All but one of the transconjugants were microcin B17 sensitive and synthesized alkaline phosphatase. The plasmid from the microcin B17-resistant clone was purified and analysed with restriction endonucleases. It was found to lack a $6.8 \mathrm{~kb}$ stretch of DNA from within an $8.8 \mathrm{~kb}$ $P_{s t} \mathrm{I}$ fragment of $\mathrm{pL} 719$. This fragment was cloned into the $P_{s t} \mathrm{I}$ site of $\mathrm{pBR} 322$. Strain RYC953 was transformed with a ligation mixture containing Pst I digests from $\mathrm{pL} 719$ and $\mathrm{pBR} 322$, and $\mathrm{Tc}^{\mathrm{R}}$ clones were selected. Plasmid pMM70 was found in one of the $\mathrm{Tc}^{\mathrm{R}}$ transformants which was sensitive to Ap and microcin B17. This plasmid carried both pho $A^{+}$and $s b m A^{+}$alleles. A physical map of pMM70 is presented in Fig. 1.

To localize the $s b m A$ locus on pMM70, we constructed a series of in vitro deletion derivatives. All but one of them, pMM73-3, complemented chromosomal sbmA mutations, indicating that $\operatorname{sbmA}$ is located within the $2.6 \mathrm{~kb}$ AvaI-Pst I fragment of pMM70 (Fig. 1).

lac $Z$ gene fusions in $s b m A$. In order to determine the direction of $s b m A$ transcription, we constructed $s b m A-l a c Z$ gene protein fusions in plasmid pMM73-4 using miniMudII1681 (Castilho et al., 1984). Plasmid pMM73-4 was introduced into strain POII1681, and a phage lysate was obtained from the resulting transformant. Strain RYC761 $\Delta(p h o A s b m A)$ was transduced with the lysate in nine separate experiments. Transductants which had received 


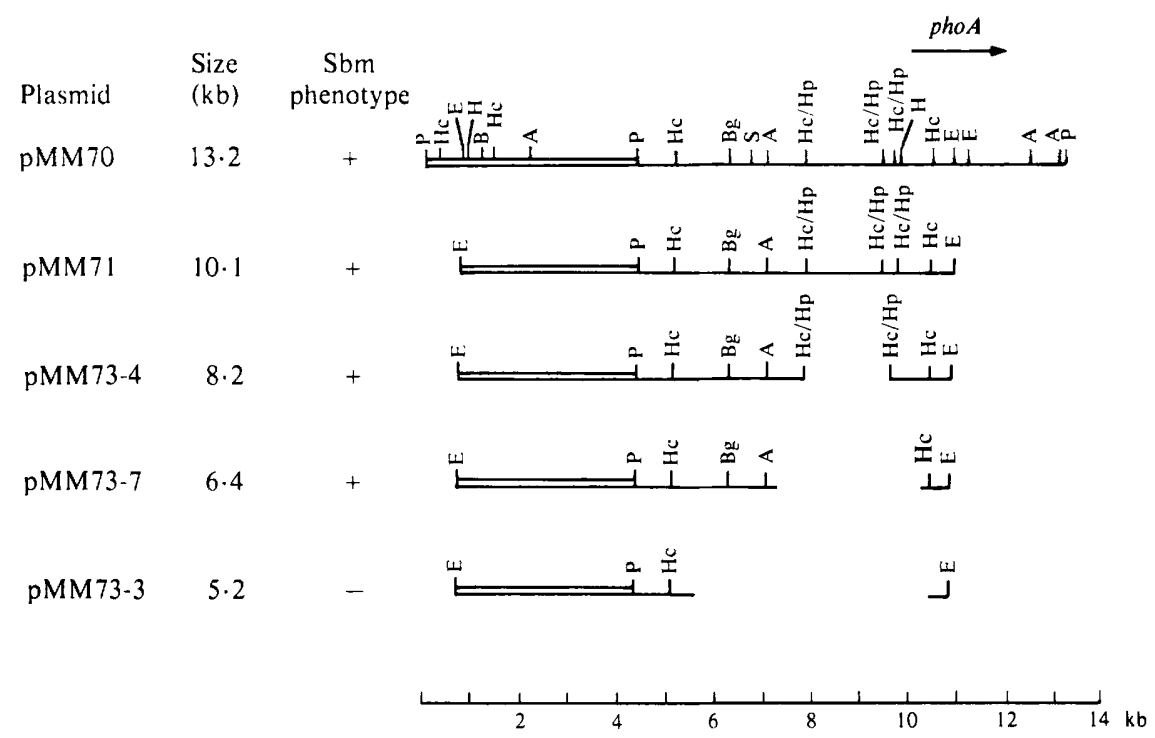

Fig. 1. Physical map of pMM70 and its derivatives. pMM70 was digested with EcoRI and religated to obtain pMM71. pMM73-4 is a deletion derivative of pMM71 obtained by digestion with HpaI. pMM73-7 and pMM73-3 were obtained in the same way, but are smaller than pMM73-4 due to an exonuclease activity in the $H p a I$ preparation. The arrow indicates the position and direction of transcription of the phoA gene (Sarthy et al., 1981). The restriction pattern of this region coincides with those already described for the phoA locus (Berg, 1981; Inouye et al., 1981; Boidol et al., 1982). Only pMM70 is able to complement phoA mutations.,- pBR322; $\square$, cloned DNA; P, PstI; Hc, HincII; Bg, BglII; S, SacII; A, AvaI; Hp,HpaI; H, HindIII; E, EcoRI; B, BamHI.

pMM73-4 $\left(\mathrm{Tc}^{\mathrm{R}}\right)$ and MudII1681 $\left(\mathrm{Km}^{\mathrm{R}}\right)$ and which retained their microcin B17 resistance were selected on M63 glucose X-gal plates supplemented as indicated in Methods. Approximately $17 \%$ of the transductants were $\mathrm{Lac}^{+}$and, therefore, likely to carry $\operatorname{sbmA-lacZ}$ gene fusions created by insertion of MudII1681 into $\operatorname{sbmA}$. Nine independent $\mathrm{Lac}^{+}$clones were selected for further analysis. Each contained a plasmid of about $22.4 \mathrm{~kb}$ (comprising the $8.2 \mathrm{~kb}$ of pMM73-4 and the $14.2 \mathrm{~kb}$ of MudII1681) which could transform LacZ $\mathrm{L}^{-}$strains to $\mathrm{Lac}^{+}$, but which could not complement $\operatorname{sbmA}$ mutations. These plasmids were digested with PstI and BamHI restriction endonucleases in order to determine the orientation and position of the MudII1681 insertions (Fig. 2). All of the insertions were within a $1050 \mathrm{bp}$ length of DNA within the PstI$B g / I I$ fragment of pMM73-4. They were all orientated in the same direction, with lac $Z$ being read from the PstI end of the fragment towards the $B g l \mathrm{II}$ end. By relating these results to the known positions of phoA and $\operatorname{sbmA}$ in pMM70 and in the E. coli K12 chromosome (Fig. 1) (Bachmann, 1983), we can deduce that $\operatorname{sbm} A$ is transcribed in a clockwise direction in the E.coli chromosome.

$\beta$-Galactosidase activities in strains carrying plasmids with $s b m A-l a c Z$ gene fusions were relatively low (Fig. 2).

Cloning of sbmA in pUC13. We have studied the protein profiles of cell envelope and soluble fractions from strains carrying wild-type or mutant $\operatorname{sbm} A$ alleles, and from strains carrying pMM70 and its deletion derivatives, by SDS-PAGE, but have consistently failed to identify any protein which could correspond to the $\operatorname{sbmA}$ gene product. The presence of pMM70 and its $\mathrm{SbmA}^{+}$derivatives did not increase sensitivity to microcin $\mathrm{B} 17$, suggesting that either the $\operatorname{sbmA}$ gene product was not overproduced or it was not limiting for microcin B17 action. In order to increase SbmA production, we cloned the $1.75 \mathrm{~kb} P s t \mathrm{I}-B g l \mathrm{II}$ fragment of pMM73-4 into pUC13 in the hope of expressing $\operatorname{sbm} A$ from the lac $Z$ promoter. Transformants carrying this recombinant plasmid (pMM90) were indeed about four times more sensitive to microcin B17 


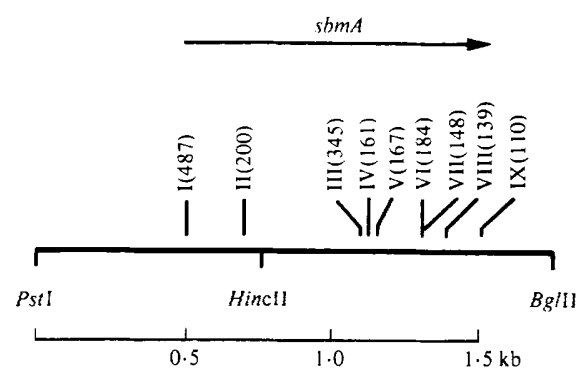

Fig. 2. Localization of MudII1681 insertions producing $s b m A:: \operatorname{lac} Z$ gene fusions in pMM73-4. The $1.75 \mathrm{~kb}$ Pst I-Bg/II fragment of pMM73-4 is shown. The fusions are numbered I to IX, and the pointers indicate the sites where MudIII68I was inserted. The sites were determined by digestion with restriction endonucleases $B a m H I$ and Pst I and are based on the known positions of these sites in pMM73-4 (this study) and in MudII1681 (Castilho et al., 1984; O'Conner \& Malamy, 1983; Jorgensen et al.. 1979). Values in parentheses are $\beta$-galactosidase activities (Miller units); for comparison, lac $Z$ gene fusions to the colicin E2 structural gene promoter $(c e a B p)$ in pBR322 derivatives yield $8000-30000$ units of $\beta$-galactosidase.

than wild-type cells, suggesting that an increase in the level of $s b m A$ gene expression had been achieved. However, we were still unable to detect a putative $\operatorname{sbm} A$ gene product. All these experiments were done in cells carrying pMM100, a multiple copy number plasmid carrying the lac $^{I^{11}}$ repressor allele, and in the absence of induction by IPTG. Clones carrying pMM90 in the absence of lacI-encoded repressor, or even in the presence of pAPIP502 $\left(\mathrm{F}^{\prime} l a c^{q 1}\right)$, were unstable, grew poorly and tended to produce microcin-resistant subclones. IPTG induction of cells carrying pMM90 and pMM100 also caused a rapid loss of viability. We conclude that overexpression of $s b m A$ may be lethal.

\section{DISCUSSION}

Mutations in three chromosomal genes, $o m p F, o m p R$ and the previously undescribed gene which we have named $s b m A$, affect sensitivity to microcin B17. If we consider that $s b m A$ constitutes a single cistron, it could encode a protein of $\geqslant 40 \mathrm{kDa}$. Experiments with $s b m A-l a c Z$ gene fusions indicate that $s b m A$ is probably poorly expressed, which is consistent with the fact that we have so far been unable to detect the $\operatorname{sbm} A$ gene product, either by examining fractionated cells by SDS-PAGE, or by labelling plasmid-encoded proteins in maxicell or minicell systems (data not shown).

The results we have obtained do not allow us to define the roles of the ompF,ompR and $s b m A$ gene products in microcin B17 action. It is possible that OmpF protein plays a role in the penetration of the $E$. coli $\mathrm{K} 12$ outer membrane by microcin $\mathrm{B} 17$, as it does for several colicins (Konisky, 1979; Pugsley, 1984). Our results show that OmpC protein is only partially able to replace OmpF protein with respect to microcin B17 action, as is the case with colicins such as E2 and E3 (Mock \& Pugsley, 1982). These major outer membrane proteins may either function as pores to allow the passage of the microcin/colicin across the membrane, or may help to stabilize or activate the microcin/colicin receptor. The former hypothesis seems more likely in the case of microcin B17 than for colicins such as E2 or E3, because microcins are considerably smaller (Baquero \& Moreno, 1984).

The role of the $\operatorname{sbm} A$ gene product in microcin B17 action remains to be defined. Mutations affecting $\operatorname{sbm} A$, and even deletions of the entire gene, do not affect cell growth, indicating that the $\operatorname{sbm} A$ product is not essential for cell viability. The fact that $\operatorname{sim} A$ mutations lead to very high levels of microcin B17 resistance indicates that it codes for a key product for microcin action. The following results indicate that the $s b m A$ gene may code for, or is required for, the synthesis of an envelope protein, possibly the microcin B17 receptor. (a) Exogenous microcin B17 kills susceptible bacteria, and induces genes involved in the SOS repair system in susceptible and immune strains (Herrero \& Moreno, 1986; Herrero et al., 1986). These effects 
are not observed in $s b m A$ mutants. (b) Microcin-producing cells exhibit levels of SOS gene expression (measured with a sfiA-lacZ operon fusion) which are higher than those in cells without plasmids or in cells harbouring non-producing plasmid derivatives. When cells carried the wild-type plasmid pMccB17, in which microcin production is balanced with immunity, the level of $\Phi(s f A-l a c Z)$ expression was twice the basal level. This stimulation in SOS expression was completely abolished when the producer cells carried the $s b m A 1$ mutation (Herrero et al., 1986). A similar situation has been described previously with cells carrying plasmids encoding colicin E2, which has endodeoxyribonuclease activity, and hence induces the SOS system. Mutations affecting colicin E2 uptake (btuB or ompF/ompR) in the colicin producer cells eliminated the SOS stimulation effect. It was concluded that the effect was due to colicin, which, after being released into the medium, entered other cells in the culture, overcoming their immunity and thus exerting its effects (Pugsley, 1983; Pugsley et al., 1983). (c) When cells harboured pMM102, a plasmid in which the balance between microcin production and immunity was altered, during its construction, in favour of production (unpublished), $\Phi(s f i A-$ $l a c Z$ ) was expressed at levels as high as 15 times the basal value (Herrero, 1984). In this case, the introduction of the $s b m A l$ mutation reduced, but did not abolish, the activation of $\Phi(s f i A-l a c Z)$, which was expressed at four times the basal level (Herrero, 1984). These results indicate that $s b m A l$ did not prevent the action of endogenous microcin that had not been neutralized because of the inbalance between production and immunity. (d) Further support for this view came from the behaviour of strains carrying pMMl02 and a recA mutation. As indicated in the Introduction, $\operatorname{rec} A$ and $\operatorname{rec} B C$ mutants are extremely sensitive to microcin. When these cells carry pMM102 they cannot grow in minimal medium in which microcin production is 'optimal'. This property, which is due to the inbalance between production and immunity (San Millán et $a l ., 1985 a$; unpublished), could neither be suppressed by the introduction of $s b m A$ mutations, nor by $\operatorname{omp} R$ mutations. Hence these mutations protect cells from exogenous, but not from endogenous, microcin. We are, at present, attempting to select chromosomal mutations which prevent the action of endogenous microcin B17.

In conclusion, our results indicate that $s b m A$ mutants remain sensitive to microcin produced by and acting within the producer cell. The product of the $s b m A$ gene is therefore needed only for the action of exogenous microcin, and hence is likely to play a role in microcin uptake. The preparation of radio-labelled microcin for use in binding assays will be required to demonstrate whether the $\operatorname{sbmA}$ product is indeed the microcin B17 receptor. The low level of microcin activity so far recovered, even from cultures of overproducing strains, is insufficient for this purpose.

We thank M. Herrero and M. Schwartz for useful discussions, J. Talavera and S. Estrada for technical assistance and B. Bachman, M. Casadaban, S. Michaelis and R. Portalier for strains. This work was supported by grants from the Fondo de Investigaciones Sanitarias (FIS) of Ministerio de Sanidad (Spain), and in part by the 'Programme Général des Relations Scientifiques Hispano-Françaises' (Ministères des Affaires Etrangères, France). M. L. was a recipient of a fellowship included in a Plan Concertado granted by the Comisión Asesora de Investigación Cíentifica y Técnica (Spain).

\section{REFERENCES}

Asensio, C., Pérez díaz, J. C., Martínez, M. C. \& BAQUero, F. (1976). A new family of low molecular weight antibiotics from Enterobacteria. Biochemical and Biophysical Research Communications 69, 7-14.

BaCHMANN, B. J. (1983). Linkage map of Escherichia coli K12. Edition 7. Microbiological Reviews 47, 180230.

Baquero, F. \& Moreno, F. (1984). The microcins. FEMS Microbiology Letters 23, 117-124.

Baquero, F., Bouanchaud, D., Martínez, M. C. \& FERNANDEZ, C. (1978). Microcin plasmids: a group of extrachromosomal elements coding for lowmolecular-weight antibiotics in Escherichia coli. Journal of Bacteriology 135, 342-347.
BERG, D. E. (1977). Insertion and excision of a transposable kanamycin resistance determinant Tn5. In DNA Insertion Elements, Plasmids and Episomes, pp. 205-212. Edited by A. I. Bukhari, J. A. Shapiro, S. L. Adhya. Cold Spring Harbor, NY: Cold Spring Harbor Laboratory.

BERG, P. E. (1981). Cloning and characterization of the Escherichia coligene coding for the alkaline phosphatase. Journal of Bacteriology 146, 660-667.

BoIdol, W., Simonis, M., TOPERT, M. \& Siewert, G. (1982). Recombinant plasmids with genes for the biosynthesis of alkaline phosphatase of Escherichia coli. Molecular and General Genetics 185, 510512 . 
Calos, M. P. \& Miller, J. H. (1981). The DNA sequence change resulting from the lac $\mathrm{I}^{41}$ mutation which greatly increases promoter strength. Molectlar and General Genetics 183, 559-560.

Casadaban, M. (1976). Transposition and fusion of the lac genes to selected promoters in $E$. coli using bacteriophage lambda and Mu. Journal of Molecular Biology 104, 541-555.

Castillo, B. A., Olfson, P. \& Casadaban, M. J. (1984). Plasmid insertion mutagenesis and lac gene fusion with mini-Mu bacteriophage transposons. Journal of Bacteriology 158, 488-495.

Clarke, L. \& Carbon, J. (1976). A colony bank containing synthetic ColEl hybrid plasmids representative of the entire Escherichia coli genome. Cell 9, 91-99.

Datta, D. B., ARden, B. \& Henning, U. (1977). Major proteins of the Escherichia coli outer cell envelope membrane as bacteriophage receptors. Journal of Bacteriology 131, 821-829.

Davis, R. W., Botstein, D. \& Roth, J. R. (1980). Advanced Bacterial Genetics. Cold Spring Harbor, NY: Cold Spring Harbor Laboratory.

Hall, M. N. \& Silhavy, T. J. (1979). Transcriptional regulation of Escherichia coli K12 major outer membrane protein 1b. Journal of Bacteriology: 140 , $342-350$.

Hall, M. N. \& Silhavy, T. J. (1981). The $o m p B$ locus and the regulation of the major outer membrane porin proteins of Escherichia coli K12. Journal of Molecular Biology 146, 23-43.

HANKTE, K. (1978). Major outer membrane proteins of Escherichia coli $\mathrm{K} 12$ serve as receptors for the phage T2 (protein 1a) and 434 (protein 1b). Molecular and General Genetics 164, 131-135.

Hernández-Chico, C., Herrero, M., Rejas, M., San Millán, J. L. \& MoReno, F. (1982). Gene ompR and regulation of microcin 17 and colicin E2 syntheses. Journal of Bacteriology 152, 897-900.

HERRERO, M. (1984). Estudios sobre el modo de accion de la microcina B17. PhD thesis, Universidad Complutense de Madrid, Spain.

Herrero, M. \& Moreno, F. (1986). Microcin B17 blocks DNA replication and induces the SOS system in Escherichia coli. Journal of General Microbiology 132, 393-402.

Herrero, M., Kolter, R. \& Moreno, F. (1986). Effects of microcin B17 on microcin B17-immune cells. Journal of General Microbiology 132, 403-410.

INOUYe, H., MichaELIS, S., WRIGHT, A. \& BECKWITH, J. (1981). Cloning and restriction mapping of the alkaline phosphatase structural gene ( $p h o A)$ of Escherichia coli and generation of deletion mutants "in vitro". Journal of Bacteriology 146, 668-675.

JoRgENSEN, R. A., RothsteIN, S. J. \& REzNIKoFF, W. S. (1979). A restriction enzyme cleavage map of Tn5 and location of a region encoding neomycin resistance. Molecular and General Genetics 177, 65-72.

KONISKY, J. (1979). Specific transport systems and receptors for colicins and phages. In Bacterial Outer Membranes. Biogenesis and Functions. Edited by M. Inouye. New York: Wiley.

Low, K. B. (1972). Escherichia coli K 12 F-prime factors old and new. Bacteriological Reviews 36, 587-607.

Maniatis, T., Fritsch, E. F. \& Sambrook, J. (1982). Molecular Cloning: a Laboratory Manual. Cold Spring Harbor, NY: Cold Spring Harbor Laboratory.

Mayr-Harting, A., Hedges, A. J. \& Berkeley, R. C. W. (1972). Methods for studying bacteriocins. Methods in Microbiology 7A, 315-422.

MEssing, J. (1983). New M13 vectors for cloning. Methods in Enzlmology 101, 20-78.

Miller, J. H. (1972). Experiments in Molecular Genetics. Cold Spring Harbor, NY: Cold Spring Harbor Laboratory.

Mock, M. \& Pugsley, A. P. (1982). The BtuB group Col plasmids and homology between the colicins they encode. Journal of Bacteriology' 150, 1069-1076.

Neidhardt, F. C., Bloch, P. L. \& SMith, D. F. (1974). Culture medium for Enterobacteria. Journal of Bacteriology 119, 736-747.

O'Conner, H. B. \& Malamy, M. H. (1983). A new insertion sequence, ISI2l is found on the Mud II (Aplac) bacteriophage and the Escherichia coli chromosome. Journal of Bacteriology 156, 669-679.

PugsLey, A. P. (1983). Autoinduced synthesis of colicin E2. Molecular and General Genetics 190, 379 383.

Pugsley, A. P. (1984). The ins and outs of colicins. Parts I and II. Microbiological Sciences 1, 168-205.

Pugsley, A. P. (1985). Escherichia coli K 12 strains for use in the identification and characterization of colicins. Journal of General Microbiology 131, 369376.

Pugsley, A. P., Schwartz, M., Lavina, M. \& MORENO, F. (1983). On the effect of $o m p R$ on colicin E2 production. FEMS Microbiology Letters 19, 8792.

Sanger, F., Coulson, A. R., Friedmann, T., Air, G. M., Barrell, B. G., Brown, N. L., Fidoles, J. C., Autchison iII, C. A., Slocombe, P. H. \& SMITH, M. (1978). The nucleotide sequence of bacteriophage $\phi \times 174$. Journal of Molecular Biology $125,225-246$.

Sanger, F., Coulson, A. R., Hong, G. F., Hill, D. F. \& Petersen, G. B. (1982). Nucleotide sequence of bacteriophage lambda DNA. Journal of Molecular Biology 162, 729-773.

San Millán, J. L., Hernández-Chico, C., Pereda, P. \& Moreno, F. (1985a). Cloning and mapping of the genetic determinants for microcin B17 production and immunity. Journal of Bacteriology 163, 275-281.

San Millán, J. L., Kolter, R. \& Moreno, F. (1985b). Plasmid genes required for microcin B 7 production. Journal of Bacteriology 163, 1016-1020.

Sarthy, A., Michaelis, S. \& Beckwith, J. (1981). Use of gene fusions to determine the orientation of the phoA gene on the Escherichia coli chromosome. Journal of Bacteriology 145, 293-298. 